\title{
Front Matter: Volume 9997
}

, "Front Matter: Volume 9997," Proc. SPIE 9997, Target and Background Signatures II, $99970 U$ (30 November 2016); doi: 10.1117/12.2263830

SPIE. Event: SPIE Security + Defence, 2016, Edinburgh, United Kingdom 


\section{PROCEEDINGS OF SPIE}

\section{Target and Background Signatures II}

Karin U. Stein

Ric H. M. A. Schleijpen

Editors

26-27 September 2016

Edinburgh, United Kingdom

Sponsored by

SPIE

Cooperating Organisations

Innovation Centre for Sensor and Imaging Systems (United Kingdom)

ADS Scotland (United Kingdom)

The Knowledge Transfer Network (United Kingdom)

Visit Scotland (United Kingdom)

European Regional Development Fund (Belgium)

Technology Scotland (United Kingdom)

Published by

SPIE 
The papers in this volume were part of the technical conference cited on the cover and title page. Papers were selected and subject to review by the editors and conference program committee. Some conference presentations may not be available for publication. Additional papers and presentation recordings may be available online in the SPIE Digital Library at SPIEDigitallibrary.org.

The papers reflect the work and thoughts of the authors and are published herein as submitted. The publisher is not responsible for the validity of the information or for any outcomes resulting from reliance thereon.

Please use the following format to cite material from these proceedings:

Author(s), "Title of Paper," in Target and Background Signatures II, edited by Karin U. Stein, Ric H. M. A. Schleijpen, Proceedings of SPIE Vol. 9997 (SPIE, Bellingham, WA, 2016) Six-digit Article CID Number.

ISSN: 0277-786X

ISSN: 1996-756X (electronic)

ISBN: 9781510603981

ISBN: 9781510603998 (electronic)

Published by

SPIE

P.O. Box 10, Bellingham, Washington 98227-0010 USA

Telephone +1 3606763290 (Pacific Time) · Fax +1 3606471445

SPIE.org

Copyright @ 2016, Society of Photo-Optical Instrumentation Engineers.

Copying of material in this book for internal or personal use, or for the internal or personal use of specific clients, beyond the fair use provisions granted by the U.S. Copyright Law is authorized by SPIE subject to payment of copying fees. The Transactional Reporting Service base fee for this volume is $\$ 18.00$ per article (or portion thereof), which should be paid directly to the Copyright Clearance Center (CCC), 222 Rosewood Drive, Danvers, MA 01923. Payment may also be made electronically through CCC Online at copyright.com. Other copying for republication, resale, advertising or promotion, or any form of systematic or multiple reproduction of any material in this book is prohibited except with permission in writing from the publisher. The CCC fee code is 0277-786X/15/\$18.00.

Printed in the United States of America.

Publication of record for individual papers is online in the SPIE Digital Library.

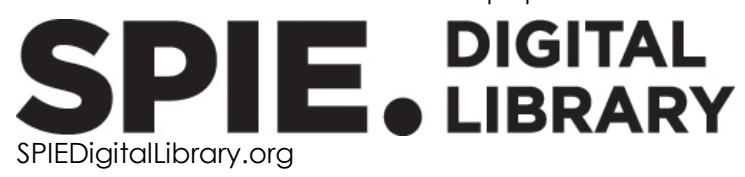

Paper Numbering: Proceedings of SPIE follow an e-First publication model. A unique citation identifier (CID) number is assigned to each article at the time of publication. Utilization of CIDs allows articles to be fully citable as soon as they are published online, and connects the same identifier to all online and print versions of the publication. SPIE uses a six-digit CID article numbering system structured as follows:

- The first four digits correspond to the SPIE volume number.

- The last two digits indicate publication order within the volume using a Base 36 numbering system employing both numerals and letters. These two-number sets start with 00, 01, 02, 03, 04, 05, 06, 07, $08,09,0 A, 0 B \ldots 0 Z$, followed by 10-1Z, 20-2Z, etc. The CID Number appears on each page of the manuscript. 


\title{
Contents
}

\author{
$\checkmark$ Authors \\ vii Conference Committee
}

\section{SESSION 1 UAV DETECTION}

999701 Detection of acoustic, electro-optical and RADAR signatures of small unmanned aerial vehicles (Invited Paper) [9997-1]

999702 Detection of mini-UAVs in the presence of strong topographic relief: a multisensor perspective [9997-2]

999703 High infrasonic goniometry applied to the detection of a helicopter in a high activity environment [9997-3]

999704 Numerical RCS and micro-Doppler investigations of a consumer UAV [9997-4]

999705 Spurious RF signals emitted by mini-UAVs [9997-5]

999706 Near-infrared high-resolution real-time omnidirectional imaging platform for drone detection [9997-6]

999707 Visual signature reduction of unmanned aerial vehicles [9997-7]

999708 Evaluation of experimental UAV video change detection [9997-8]

\section{SESSION 2 CAMOUFLAGE EFFECTIVENESS}

9997 OA Disruptive coloration in woodland camouflage: evaluation of camouflage effectiveness due to minor disruptive patches [9997-10]

9997 OB Modelling vehicle colour and pattern for multiple deployment environments [9997-12]

9997 OC Camouflage in thermal IR: spectral design [9997-13]

\section{SESSION $3 \quad$ MULTI-/HYPERSPECTRAL SIGNATURES}

9997 OE Tasks and tools for battlefield reconnaissance (Invited Paper) [9997-15]

9997 OF High dynamic range hyperspectral imaging for camouflage performance test and evaluation [9997-16]

9997 OG Pixelated camouflage patterns from the perspective of hyperspectral imaging [9997-17] 
$9997 \mathrm{OH}$ Determination of target detection limits in hyperspectral data using band selection and dimensionality reduction [9997-18]

999701 Multiwaveband simulation-based signature analysis of camouflaged human dismounts in cluttered environments with TAIThermIR and MUSES [9997-19]

\section{SESSION 4 IMAGE INTERPRETATION I}

9997 0J Multiscale image fusion through guided filtering [9997-20]

9997 OK Asynchronous threat awareness by observer trials using crowd simulation [9997-21]

\section{SESSION 5 IMAGE INTERPRETATION II}

9997 OL Computationally efficient target classification in multispectral image data with Deep Neural Networks (Best Student Paper Award) [9997-22]

9997 OM Multi-agent system for line detection on images [9997-23]

\section{SESSION 6 SIGNATURE AND SCENE MODELLING}

9997 OP Utilising E-on Vue and Unity 3D scenes to generate synthetic images and videos for visible signature analysis [9997-27]

$99970 Q \quad$ Atmospheric visibility estimation and image contrast calibration [9997-28]

9997 OR Development of an atmospheric infrared radiation model with high clouds for target detection [9997-29]

\section{POSTER SESSION}

9997 OS Thermal transmission of camouflage nets revisited [9997-30]

9997 OT A novel approach to simulate chest wall micro-motion for bio-radar life detection purpose [9997-31] 


\section{Authors}

Numbers in the index correspond to the last two digits of the six-digit citation identifier (CID) article numbering system used in Proceedings of SPIE. The first four digits reflect the volume number. Base 36 numbering is employed for the last two digits and indicates the order of articles within the volume. Numbers start with 00, 01, 02, 03, 04, 05, 06, 07, 08, 09, 0A, 0B...0Z, followed by 10-1Z, 20-2Z, etc.

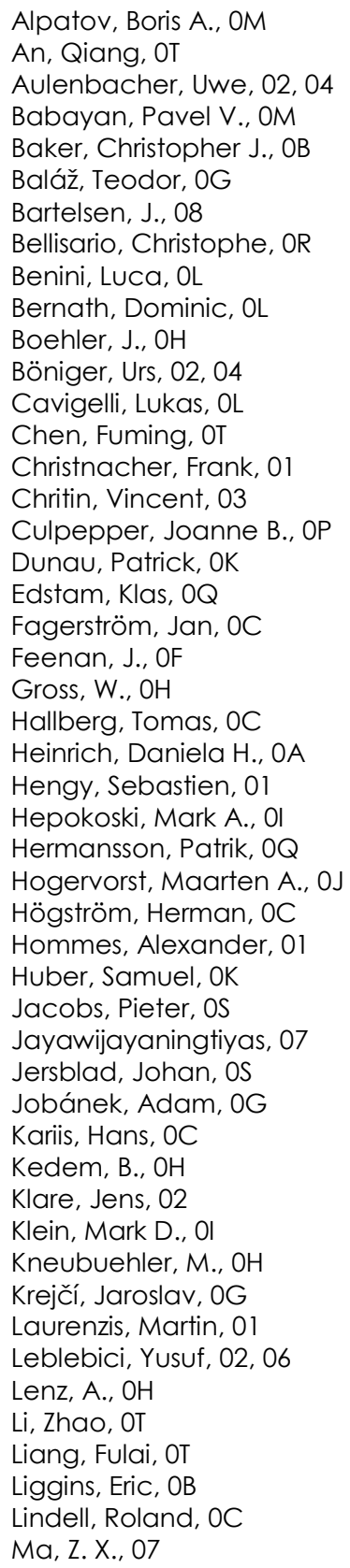

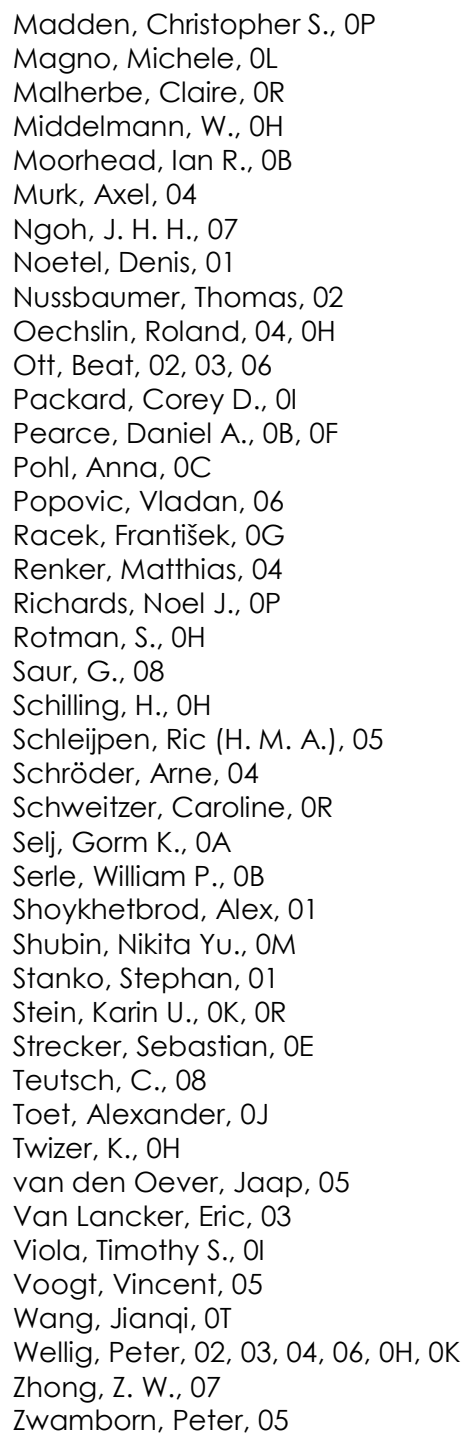


Proc. of SPIE Vol. $999799970 U-6$

Downloaded From: https://www.spiedigitallibrary.org/conference-proceedings-of-spie on 26 Apr 2023 Terms of Use: https://www.spiedigitallibrary.org/terms-of-use 


\title{
Conference Committee
}

\author{
Symposium Chair
}

David H. Titterton, UK Defence Academy (United Kingdom)

Symposium Co-Chairs

Ric H. M. A. Schleijpen, TNO Defence, Security and Safety (Netherlands)

Karin U. Stein, Fraunhofer-Institut für Optronik, Systemtechnik und Bildauswertung (Germany)

Stuart S. Duncan, SELEX ES Ltd. (United Kingdom)

Conference Chairs

Karin U. Stein, Fraunhofer-Institut für Optronik, Systemtechnik und Bildauswertung (Germany)

Ric H. M. A. Schleijpen, TNO Defence, Security and Safety (Netherlands)

Conference Programme Committee

Joanne B. Culpepper, Defence Science and Technology Group (Australia)

Willem H. Gunter, Institute for Maritime Technology (South Africa)

Daniela H. Heinrich, Norwegian Defence Research Establishment (Norway)

Katrin Idla, Tallinn University of Technology (Estonia)

Hans M. Kariis, Swedish Defence Research Agency (Sweden)

Alexander Schwarz, Fraunhofer-Institut für Optronik, Systemtechnik und Bildauswertung (Germany)

Miranda van lersel, TNO Defence, Security and Safety (Netherlands)

Peter Wellig, Armasuisse (Switzerland)

Session Chairs

1 UAV Detection

Peter Wellig, Armasuisse (Switzerland)

2 Camouflage Effectiveness

Hans M. Kariis, FOI-Swedish Defence Research Agency (Sweden)

3 Multi-/Hyperspectral Signatures

Marek Strandberg, Tallinn University of Technology (Estonia) 
4 Image Interpretation I

Karin U. Stein, Fraunhofer-Institut für Optronik, Systemtechnik und Bildauswertung (Germany)

5 Image Interpretation II

Patrick Danau, Fraunhofer-Institut für Optronik, Systemtechnik und Bildauswertung (Germany)

6 Signature and Scene Modelling

Ric H. M. A. Schleijpen, TNO Defence, Security and Safety (Netherlands) 